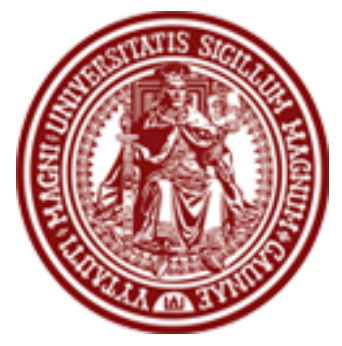

BALTIC JOURNAL OF LAW \& POLITICS

VOLUME 7, NUMBER 1 (2014)

ISSN 2029-0454

http://www.degruyter.com/view/j/bjlp

Cit.: Baltic Journal of Law \& Politics 7:1 (2014): 1-11

DOI: $10.2478 / b j l p-2014-0001$

\title{
TOWARDS AN AMERICAN MODEL OF CRIMINAL PROCESS: THE REFORM OF THE POLISH CODE OF CRIMINAL PROCEDURE
}

\author{
Monika Roclawska \\ Ph.D. Student \\ Nicolaus Copernicus University in Torun, Faculty of Law (Poland) \\ Contact information \\ Address: Ul. Władysława Bojarskiego 3, 87-100 Toruń, Poland \\ Phone: +48606916 654 \\ E-mail address: rolos@poczta.fm
}

\author{
Adam Bulat \\ Ph.D. Student \\ Nicolaus Copernicus University in Torun, Faculty of Law (Poland) \\ Contact information \\ Address: Ul. Władysława Bojarskiego 3, 87-100 Toruń, Poland \\ Phone: +48697150871 \\ E-mail address: adam.bulat@vp.pl
}

Received: December 30, 2013; reviews: 2; accepted: May 5, 2014.

\footnotetext{
ABSTRACT

In September 2013, the Polish Parliament passed an amendment to the Code of Criminal Procedure. The legislators decided to expand a number of adversarial elements present in current Polish criminal proceedings. When these changes come into effect (July 1, 2015), Polish criminal procedure will be similar to American regulations, in which the judge's role is to be an impartial arbitrator, not an investigator.

The authors of the article describe the meaning of the principle of adversarial trial in Poland. They also emphasized relations between this principle and the concept of "material truth". The changes established by the amendment are shown in perspective of the American definition of adversarial trial. The authors analyze the reform and attempt to predict the problems with new regulations in practice.
} 


\section{KEYWORDS}

Polish criminal procedure, American criminal procedure, principle of adversarial trial, concept of "material truth" 


\section{INTRODUCTION}

In September 2013, the Polish Parliament passed an amendment to the Code of Criminal Procedure. According to the authors of the amendment, the current model of Polish criminal procedure requires in-depth changes for a plethora of reasons, the most prominent one being the excessive length of the proceedings. The Criminal Law Codification Commission considers that one of the remedies to hasten the lethargic procedure of Polish criminal process is to expand a number of adversarial elements present nowadays. The findings of the Commission seem to conform to the presence of a direct connection between the lengthy time of the proceedings and the inquisitorial investigation of the facts. ${ }^{1}$

In the legal doctrine of the Polish criminal procedure, the principle of adversarial trial is recognized as a directive, according to which a directly interested party in the investigation process has the right to fight with the opponent side for a positive outcome for themselves. ${ }^{2}$ Śliwiński also enumerates the roles of participants in the trial, which are: prosecution, defense and adjudication. ${ }^{3}$ According to some representatives of the Polish legal doctrine, one of the prerequisites for the adversarial process is the existence of equal, adverse parties before the court, which are waging a fight before the impartial arbiter. ${ }^{4}$

The principle of adversarial trial is in juxtaposition to the inquisitorial principle, which means that, in the model approach, in the inquisitorial process there will be no separate parties, and the judicial triumvirate rests in the hands of a single body. ${ }^{5}$ It should be noted that there is currently no country in which one of the above mentioned models would occur in its pure form. ${ }^{6}$

\footnotetext{
${ }^{1}$ The explanatory memorandum to the Criminal Law Codification Commission's bill, Sejm Form no. 870, p. 1-2.

2 Marian Cieślak, Dzieła wybrane. Tom II. Polska procedura karna. Podstawowe założenia teoretyczne [Selected Works. Volume II. Polish criminal procedure. The basic theoretical assumptions] (Cracow: Jagiellonian University Press, 2011), p. 206.

${ }^{3}$ Stanisław Śliwiński, Polski proces karny przed sądem powszechnym. Zasady ogólne. Wydanie II [Polish criminal process before the court. General principles. Edition II] (Warsaw: Lawyers Publishing House, $1961)$, p. 66.

${ }^{4}$ Zofia Świda, ed., Postępowanie karne. Cześć ogólna [The criminal proceedings. General part] (Warsaw: Wolters Kluwer, 2008), p. 52; Stanisław Waltoś and Piotr Hofmański, Proces karny. Zarys systemu [Criminal process. Outline of the systems] (Warsaw: LexisNexis, 2013), p. 276.

5 Tomasz Grzegorczyk and Janusz Tylman, Polskie postępowanie karne wyd. 8 [Polish criminal proceedings, 8 ed.] (Warsaw: LexisNexis, 2011), p. 123.

${ }^{6}$ Arkadiusz Lach, "Zasada kontradyktoryjności w postępowaniu sądowym w procesie karnym de lege lata i de lege ferenda" ["The principle of adversarial trial in a criminal proces de lege lata and de lege ferenda"], Palestra 5-6 (2012): 126.
} 


\section{THE PRINCIPLE OF ADVERSARIAL TRIAL IN POLISH AND AMERICAN CRIMINAL PROCEDURE}

The Polish criminal process is a mixed model that combines both elements of an inquisitorial and adversarial model. In a pretrial investigation, currently the principle of inquisitorial process is substantially based on equality of the parties. Conversely, the judicial proceedings are based on the principle of adversariality, albeit limited in a significant way under the present system. ${ }^{7}$ Some of the limitations to the concept of adversarial trial in the Polish criminal procedure include the judge's evidentiary initiative (167 CCP) and the obligation of the presiding judge to investigate all circumstances of vital significance to the case (366 CCP).

In addition, it should be mentioned that the next limitation to the principle of an adversarial system is found in article $14 \S 2$ CCP which states that the court shall not be bound by the public prosecutor's withdrawal of the accusation. However, as mentioned before, one of the core requirements of adversarial trial is a dispute between two parties.

It should be noted that the above limitations nullify many of the essential advantages of the pure adversary model, for instance, the objectivity of the procedural authority. ${ }^{8}$ As it is now, in a situation where the prosecutor is not active, and court still has unlimited initiative evidence, the line between the judge and prosecutor-which is essential in a pure adversarial system-gets blurred.

These limitations to the principle of contradictory trial are justifiable because of the concept of 'material truth', which is considered by many representatives of the Polish legal doctrine to be one of the fundamental aspects of Polish criminal proceedings. $^{9}$ This principle of material truth requires that the basis for any procedural decision shall be based on true facts. The fundamental guarantee of the principle of the material truth is the duty of the court and public prosecutor to gather all of the important evidence. ${ }^{10}$ This is in contrast to the pure adversarial model, which holds that "due process" is the best way to find the 'material truth' and that due process always requires two sides. ${ }^{11}$

To properly define the principle of adversarial trial one should view the best manifestation thereof, which in this case is the American criminal procedure system. There are several key features in viewing the American criminal procedure as the best adversarial model.

\footnotetext{
${ }^{7}$ Ibid.: 128.

8 Stanisław Waltoś and Piotr Hofmański, supra note 4, p. 275.

9 Katarzyna Boratyńska, Łukasz Chojniak, and Wojciech Jasiński, Postępowanie karne [Criminal procedure] (Warsaw: C.H. Beck, 2012), p. 17.

${ }^{10}$ Stanisław Waltoś and Piotr Hofmański, supra note 4, p. 219.

${ }^{11}$ Niki Kuckes, "Civil Due Process, Criminal Due Process," Yale Law \& Policy Review 25 (2006): 2.
} 
A. "Litigation is run by the parties, and not by the Court", said M. L. Corrado. ${ }^{12}$ The parties control and manage the presentation of evidence. The Prosecutor gathers evidence and attempts to prove the guilt of the accused beyond a reasonable doubt whereas the accused (or his counsel) have the right to defend against the accusations. The essence of the adversarial trial is a procedurally balanced contest between prosecution and defense. Ethically, the prosecution must reveal any exculpatory evidence, which would tend to show that the accused is not guilty. The accused, however, need not reveal any negative testimonial evidence to the prosecutor because of his privilege against self-incrimination. ${ }^{13}$

B. The rights of cross-examination belong to the prosecution and defense counsel alike. The judge and the jury remain passive and impartial. ${ }^{14}$ An accused's constitutional right is to have a fair trial before an impartial jury, which directly translates into having a fair trial before an impartial judge. ${ }^{15}$

C. The defendant is entitled to have a jury of 6 or 12 jurors, ${ }^{16}$ or the defendant may give up his right to have a jury and ask for the impartial judge to make the findings of fact. If a jury is used, the jury will decide about the essential facts of the case. ${ }^{17}$ In Polish law the institution of the jury is not used anymore; the remnant of jury use in Polish criminal proceedings can be identified in the institution of a lay judge.

D. In the American criminal procedure, the victim is not party to the proceedings. ${ }^{18}$ In US law there are not institutions such as are found in the Polish system, such as the subsidiary prosecutor, the private prosecutor or the civil plaintiff who may file a civil complaint against the accused within the framework of the criminal proceedings. ${ }^{19}$ However, in US law, a victim will be a party to civil proceedings if he or she starts a civil lawsuit (litigation) against the wrongdoer. It is a separate proceeding from the criminal proceeding. ${ }^{20}$ The burden of proof in civil proceedings is different. In order to find that the victim is entitled to restitution or money damages, a judge or civil jury needs to find the wrongdoer acted to injure

\footnotetext{
12 Michael Louis Corrado, "The Future of Adversarial Systems: An Introduction to the Papers from the First Conference," North Carolina Journal of International Law and Commercial Regulation 35 (2010): 285.

${ }^{13}$ Gary Goodpaster, "On the theory of American adversary criminal trial," The Journal of Criminal Law \& Criminology 78 (1987): 120-121.

${ }^{14}$ Roman Tokarczyk, Prawo amerykańskie [American Law] (Warsaw: Oficyna, 2011), p. 251.

${ }^{15}$ Gerald Walpin, "America's adversarial and jury systems: more likely to do justice," Harvard Journal of Law \& Public Policy 26 (2003): 183.

16 Lewis R. Katz and Neil P. Cohen, Questions \& Answers: Criminal Procedure I \& II (Newark, NJ: LexisNexis, 2003), p. 366.

17 Michael Louis Corrado, supra note 12, p. 286.

18 Ibid., p. 286.

19 See Krzysztof Stefanowicz, "The victim of the crime in Polish criminal law," Capital University Law Review 21 (1992):86-94.

20 See The National Centre for Victims of Crime, "Civil Justice for Victims of Crime" (2008): 2 // http://victimsofcrime.org/docs/NCVBA/standard-cj-bro-final.pdf?sfvrsn=2 (accessed November 21, 2013).
} 
the victim physically, financially or emotionally only by a preponderance of the evidence, a much lower standard than the criminal burden of proof required by a prosecutor in criminal proceedings which is "beyond a reasonable doubt"21.

E. Although the right to jury trial is a constitutional principle in the United States, more than $95 \%{ }^{22}$ of criminal cases are conducted by plea-bargaining. A wide range of negotiations between the prosecution and the defense is the result of the discretionary power of the Prosecutor. ${ }^{23}$ The subject of the "bargain" may be a reduction in the severity of the charges or a reduction in the possible jail sentence or other penalty. ${ }^{24}$ If the defendant and the Prosecutor reach a plea bargain agreement before trial, and the Court accepts the plea bargain, no criminal trial shall be conducted because of the absence of a dispute. The victim has no input into whether a plea bargain is offered or is acceptable. ${ }^{25} \mathrm{~A}$ victim cannot "force" a trial. However, the victim has the right to speak before the Court sentences the accused. In Polish criminal law the practice indicated above cannot be used because of the principle of material truth and the principle of legalism. ${ }^{26}$

\section{THE REFORM OF THE POLISH CODE OF CRIMINAL PROCEDURE}

In the explanatory memorandum to the Polish act of Parliament amending the Code of Criminal Procedure, it concludes that the reform of criminal proceedings in the direction of adversarial will operate to create the best conditions to clarify the material truth. ${ }^{27}$ Moreover, in the adversarial trial, the rights of the participants in the proceedings will be better respected. According to the Law Commission, remodeling the criminal process is connected with removing the burden of proof from the Court and shifting it to the parties. It is worth pointing out that for years the Polish doctrine and the practice have suggested increasing the adversarial element in criminal proceedings.

From the point of view of the reform of the CCP, the most important changes are:

${ }^{21}$ Christoph Engel, "Preponderance of the evidence versus intime conviction: a behavioral perspective on a conflict between American and Continental European law," Vermont Law Review 33(3) (2009): 435; Lewis R. Katz and Neil P. Cohen, supra note 16, p. 373.

22 John Feldmeier and Frank Schmalleger, Criminal Law and Procedure for Legal Professionals (New York: Practice Hall, 2012), p. 383.

23 Jerold Israel, Wayne LaFave, Nancy King, and Orin Kerr, Criminal Procedure, $5^{\text {th }}$ ed (Las Vegas: West Law School, 2009), p. 1034.

${ }^{24}$ Joseph Senna and Larry Siegel, Introduction to Criminal Justice, $8^{\text {th }}$ ed (Las Vegas: Cengage Learning, 1999), p. 357.

${ }^{25}$ Ibid., p. 366.

${ }^{26}$ Szymon Pawelec, "Od wniosku o skazanie bez rozprawy do negocjowania wyroków. Czy zmierzamy w stronę plea bargaining?" ["From a motion to convict the accused without conducting a trial to negotiating a sentence. Are we aiming toward plea bargaining?"]: 225; in: Cezary Kulesza, ed., Ocena funkcjonowania porozumień procesowych $w$ praktyce wymiaru sprawiedliwości [The assessment of plea agreements in practice of criminal justice] (Warsaw: Wolters Kluwer, 2009).

27 The explanatory memorandum to the Criminal Law Codification Commission's bill, Sejm Form no. 870, p. 10. 
(A) Art. $14 \S 2$ CCP. Public Prosecutor may withdraw an indictment up until the start of judicial examination. In the litigation at the court of first instance, withdrawal of the indictment is allowed only with the consent of the accused. Bringing another indictment against the same person for the same criminal act is unacceptable.

(B) Art. $167 \S 1$ CCP. In the litigation which is initiated by parties, all evidence shall be submitted by the parties, after admitting them by the court, the presiding judge or the president of the court. If the party which called the evidence does not appear on trial, the court carries out the evidence. It goes the same way, if an exceptional case justified by special circumstances happens.

(C) Art. $171 \S 2$ CCP. In addition to the proponent of the evidence who conducts the examination, the parties, defense counsel, legal representatives and experts also have the right to examine. The members of the panel are allowed to examine only if an exceptional case justified by special circumstances happens. Questions are posted directly to the person under examination unless otherwise ordered by the court or public prosecutor.

(D) Art. $335 \S 1$ CCP. The state prosecutor may, with the consent of the accused, attach to the indictment a motion to convict the accused for a crime imputed to him, without conducting a trial if circumstances surrounding the commission of the crime do not raise doubts, and the attitude of the accused indicates that the objectives of the proceedings will be achieved despite of lack of a trial. The agreement may include the issue of the cost of the litigation. It does not concern crimes for which the minimum penalty is more than 3 years' deprivation of liberty.

(E) Art. $393 \& 3$ CCP. Any private documents prepared outside the criminal proceedings may also be read aloud during trial, particularly statements, publications, letters and notes.

According to the amendment, the court should submit the evidence only if an exceptional case justified by special circumstances happens. Currently the court is submitted the evidence ex officio, as long as the factual bases are not clear. In general, the parties will submit the evidence after authorization by the court (Article $167 \S 1$ CCP). Consistently the members of the panel will be allowed to intervene only if an exceptional case justified by special circumstances happens. Nowadays, the agency that conducts the examination has an unlimited capability to examine. It means that the parties, not the court, will be responsible for finding and presenting competing versions of truth. These changes bring our Polish criminal procedure closer to the American one, where examination of testimony and documentary evidence is conducted and challenged by the parties, not by the court. 
However, the criterion of "exceptional case justified by special circumstances" is very unclear. ${ }^{28}$ There is a serious risk that this limitation may not be observed in practice, because the judges in Poland are used to explaining every questionable circumstance ex officio. If it happens, the limitations court's evidence initiative will be illusory.

One of the most important assumptions of the adversarial criminal proceedings is equal opportunity for the prosecution and defense to see and examine all of the evidence both for and against the alleged perpetrator of a crime. Of course, reaching perfect equality is impossible in practice. Polish legislators acknowledged this principle of equality of the parties by abolishing the restrictions contained in art. $393 \S 3$ CCP. That article prohibits reading aloud private documents prepared directly for the purpose of criminal proceedings. This change will help the defendant and his lawyer to prepare a more effective defense. In the US, this is called the work-product privilege against disclosure. ${ }^{29}$

According to the new regulations, the public prosecutor may decide to withdraw an indictment right up until the start of judicial examination. Then the proceedings shall be discontinued, because of the lack of dispute. Withdrawal of the indictment is allowed only with the consent of the defendant in order to give the defendant a possibility to get a judgment exonerating him. Currently the court is not bound by the public prosecutor's withdrawal of the accusation and it can continue on its own. This will change under the new regulations.

The Polish legislators also decided that an increased adversarial system will be enhanced by broadening the scope of plea bargaining. Under the amended law "the deal" between the public prosecutor and the defendant will be possible for all crimes except those most serious in which the minimum penalty is more than 3 years' deprivation of liberty. The structure of Polish plea bargaining will stay the same. It still means that punishment is the only item subject to negotiations, not the charge itself, as is frequent in the United States. Any other important issues like the factual basis, the legal classification of the crime or the number of charges will have to reflect the truth and add up with the evidence gained in the preparatory (pre-trial) proceedings. ${ }^{30}$ To sum up, we can say that in the context of the material truth rule and adversarial process it will be only "quantitative" change. After July 2015 many more criminal litigations will be ended by plea bargaining.

28 See Barbara Nita and Andrzej Światłowski, "Kontradyktoryjny proces karny (między prawda materialna a szybkościa postępowania)" ["Adversarial criminal litigation (between the material truth and velocity of proceedings"], Państwo i Prawo 1 (2012): 43-44.

${ }_{29}$ See Fred C. Zacharias, "Who owns work product?," University of Illinois Law Review 1 (2006): 129134.

${ }^{30}$ Tomasz Grzegorczyk and Janusz Tylman, supra note 5, p. 750. 


\section{CONCLUSION}

The changes contained in the Amendment Act are radical ones. However, it may be argued by analyzing the new regulations that they appear to be incomplete. On the one hand, Polish legislators want to extend the scope of adversariality based upon the common law model; however, they do not give offer solutions, and this seems to be incompatible with that model. ${ }^{31}$

The best example of this is the fact that, although Polish legislators introduce the above mentioned adversarial elements into criminal proceedings, they do not adjust the regulations concerning the principle of material truth. The result is inconsistency within the notion of adversarial trial and art. 2 \& 2 CCP, which provides that "the basis for any kind of determination shall be the established true fact situation".

The court's authority to take evidence "if an exceptional case is justified by special circumstances" does not settle if adversariality has priority over the principle of truth. In practice the preference for some 'principle of truth' is likely to make the court resort to very frequent usage of some kind of "emergency" competence. The priority of adversariality means actual redefinition of the principle of truth outside of its natural law origins. It is possible that the evidence submitted to the court by the parties will be incomplete and therefore insufficient to build the factual basis for which heretofore the application of the notion of material truth as has been utilized by the Polish criminal procedure. This problem raises another danger. The lack of clarity in the criterion of "if an exceptional case justified by special circumstances happens" means that the involvement of the judiciary may harken back to the old system and cause non-uniformity within the judicature. It can lead to increasing the discretional power of the court. However, in a democratic country the conditions of admissibility of evidence should be contained in intelligible law.

To sum up, the general direction of the changes made by the legislature in the Amendment Act are positive, because they go toward equalizing the power between the public prosecutor and defendant. There is now reasonable hope that they will be able to make criminal litigation faster and more efficient. The weakness is the very unclear criteria that still permit the court to take evidence ex officio. That is why the Supreme Court should re-amend the Act, providing answers to two questions:

1. What is more important at the level of judicial examination - the adversariality of the process, which will arrive at its own truth, or the methodology which Poland has used previously for its principle of the truth?

\footnotetext{
${ }^{31}$ Arkadiusz Lach, supra note 6: 132.
} 
2. How to clarify the criteria, which give the court the opportunity to take the evidence ex officio so that it will be uniform from court to court?

\section{BIBLIOGRAPHY}

1. Boratyńska, Katarzyna, Łukasz Chojniak, and Wojciech Jasiński. Postępowanie karne [Criminal procedure]. Warsaw: C.H. Beck, 2012.

2. Cieślak, Marian. Dzieła wybrane. Tom II. Polska procedura karna. Podstawowe założenia teoretyczne [Selected Works. Volume II. Polish criminal procedure. The basic theoretical assumptions]. Cracow: Jagiellonian University Press, 2011.

3. Corrado, Michael Louis. "The Future of Adversarial Systems: An Introduction to the Papers from the First Conference." North Carolina Journal of International Law and Commercial Regulation 35 (2010): 285-296.

4. Engel, Christoph. "Preponderance of the evidence versus intime conviction: a behavioral perspective on a conflict between American and Continental European law." Vermont Law Review 33(3) (2009): 435-468.

5. Feldmeier, John, and Frank Schmalleger. Criminal Law and Procedure for Legal Professionals. New York: Practice Hall, 2012.

6. Goodpaster, Gary. "On the theory of American adversary criminal trial." The Journal of Criminal Law \& Criminology 78 (1987): 118-154.

7. Grzegorczyk, Tomasz, and Janusz Tylman. Polskie postępowanie karne wyd. 8 [Polish criminal proceedings, 8 ed.]. Warsaw: LexisNexis, 2011.

8. Israel, Jerold, Wayne LaFave, Nancy King, and Orin Kerr. Criminal Procedure. $5^{\text {th }}$ ed. Las Vegas: West Law School, 2009.

9. Katz, Lewis R., and Neil P. Cohen. Questions \& Answers: Criminal Procedure I \& II. Newark, NJ: LexisNexis, 2003.

10. Kuckes Niki. "Civil Due Process, Criminal Due Process." Yale Law \& Policy Review 25 (2006): 1-61.

11. Lach, Arkadiusz. "Zasada kontradyktoryjności w postępowaniu sądowym w procesie karnym de lege lata i de lege ferenda" ["The principle of adversarial trial in a criminal proces de lege lata and de lege ferenda"]. Palestra 5-6 (2012): 124-138.

12. Nita, Barbara, and Światłowski Andrzej. "Kontradyktoryjny proces karny (między prawdą materialną a szybkością postępowania)" ["Adversarial criminal litigation (between the material truth and velocity of proceedings"]. Państwo i Prawo 1 (2012): 33-49. 
13. Pawelec, Szymon. "Od wniosku o skazanie bez rozprawy do negocjowania wyroków. Czy zmierzamy w stronę plea bargaining?" ["From a motion to convict the accused without conducting a trial to negotiating a sentence. Are we aiming toward plea bargaining?"]: 218-226. In: Cezary Kulesza, ed. Ocena funkcjonowania porozumień procesowych w praktyce wymiaru sprawiedliwości [The assessment of plea agreements in practice of criminal justice]. Warsaw: Wolters Kluwer, 2009.

14. Senna, Joseph, and Larry Siegel. Introduction to Criminal Justice. $8^{\text {th }}$ ed. Las Vegas: Cengage Learning, 1999.

15. Stefanowicz, Krzysztof. "The victim of the crime in Polish criminal law." Capital University Law Review 21 (1992): 86-94.

16. Śliwiński, Stanisław. Polski proces karny przed sądem powszechnym. Zasady ogólne. Wydanie II [Polish criminal process before the court. General principles. Edition II]. Warsaw: Lawyers Publishing House, 1961.

17. Świda, Zofia, ed. Postępowanie karne. Cześć ogólna [The criminal proceedings. General part.]. Warsaw: Wolters Kluwer, 2008.

18. The National Centre for Victims of Crime. "Civil Justice for Victims of Crime." (2008) // http://victimsofcrime.org/docs/NCVBA/standard-cj-brofinal.pdf?sfvrsn=2 (accessed November 21, 2013).

19. Tokarczyk, Roman. Prawo amerykańskie [American Law]. Warsaw: Oficyna, 2011.

20. Walpin, Gerald. "America's adversarial and jury systems: more likely to do justice." Harvard Journal of Law \& Public Policy 26 (2003): 175-186.

21. Waltoś, Stanisław, and Piotr Hofmański. Proces karny. Zarys systemu [Criminal process. Outline of the systems]. Warsaw: LexisNexis, 2013.

22. Zacharias, Fred C. "Who owns work product?" University of Illinois Law Review 1 (2006): 127-176. 